\title{
The Competence of Teacher Assistants in the Context of Working with Visually Impaired Students. Needs of the Environment and the Vision of Change
}

\begin{abstract}
Małgorzata Paplinska, The Competence of Teacher Assistants in the Context of Working with Visually Impaired Students. Needs of the Environment and the Vision of Change. Interdisciplinary Contexts of Special Pedagogy, no. 26, Poznań 2019. Pp. 319-341. Adam Mickiewicz University Press. ISSN 2300-391X. e-ISSN 2658-283X. DOI: https://doi.org/10.14746/ikps.2019.26.15

The text contains an analysis of the competence of a special education teacher, with particular emphasis on the competence of one working as a teacher assistant with blind and visually impaired students. It attempts to answer the question of what competence a teacher assistant should have. On the one hand, this competence must be a response to the current needs of students with visual impairments, their teachers and parents. In line with the current approach to inclusive education, the teacher assistant who works with visually impaired students should be equipped with a whole array of competences, especially a number of highly specialised ones. On the other hand, taking into account e.g. creative and ethical competences, universities educating future teachers of the kind are not able to equip graduates with full competences.
\end{abstract}

KEY WORDS: competencies, teacher of students with visual impairments, teacher assistant, blind students, visually impaired students 


\section{Introduction}

Contemporary challenges, resulting from changes in various areas of life of people with disabilities, entail specific actions, and often the need to change views that must keep up with contemporary expectations and needs in the field of education and rehabilitation. These changes are visible in theoretical studies and research as well as in the modification of practitioners' activities, including specialists and teachers working with students with special educational needs.

Special pedagogy has long been the field for discussion on the model of education and support for people with disabilities, which has led theorists and practitioners to develop a systemic triad. It covers special (segregation) education, integration education and inclusive education. ${ }^{1}$

The Convention on the Rights of Persons with Disabilities (2006, 2012) ensures the right of persons with disabilities to education under an inclusive education system at all levels of education, with the obligation of a rational support system directed to the individual possibilities and needs of students, without any exclusion. ${ }^{2}$ Iwona Chrzanowska draws attention to item 4 of that article, emphasizing that this support is to include employing teachers with appropriate qualifications and skills, e.g. the use of alternative methods, forms, resources, techniques, and teaching materials relevant for working with people with disabilities. ${ }^{3}$

${ }^{1}$ M. Dycht, Edukacja i wspieranie uczniów ze specjalnymi potrzebami edukacyjnymi i rozwojowymi w placówkach oświatowych w Polsce (Education and Support for Students with Special Educational and Developmental Needs in Educational Institutions in Poland), [in:] Dzieci z trudnościami rozwojowymi w młodszym wieku. Indywidualne programy edukacyjno-terapeutyczne $w$ procesie wspierania dzieci (Children with Developmental Handicaps at a Younger Age. Individual Educational and Therapeutic Programs in the Process of Supporting Children), ed. E. Śmiechowska-Petrovskij, Wydawnictwo Naukowe UKSW, Warszawa 2017, pp. 11-36.

2 The UN Convention on the Rights of Persons with Disabilities, UN, New York 2006; The UN Convention on the Rights of Persons with Disabilities, Journal of Laws of 25 October 2012, item 1169.

${ }^{3}$ I. Chrzanowska, Nauczanie inkluzyjne w doświadczeniach polskich - podstawy prawne i spoteczne uwarunkowania (Inclusive Teaching in the Polish Experience - Legal and Social Conditions). „Studia Edukacyjne” 2014, no 30, pp. 109-117. 
While analyzing the importance of inclusive education, Zdzisława Janiszewska-Nieścioruk and Marzenna Zaorska pay attention to its possibilities and strengths, as well as weaknesses and areas requiring rapid corrective action. ${ }^{4}$

Modern education, therefore, forces a change in the role and tasks of the teacher, both in the overall teaching process and the placement of the teacher in the classroom. A new challenge in the teacher's work is the increasing diversity of the school population of students, resulting from both the different pace of development of individual children, developmental disorders and irregularities, as well as from cultural diversity. ${ }^{5}$ The teacher faces numerous educational challenges that require professional preparation for working with children with special educational needs. These are also the tasks related to the organization of an educational space in which the individual needs of students will be met. Danuta Wosik-Kawala and Teresa Zubrzycka-Maciąg, citing Wincenty Okoń, emphasize "there is no pedagogical system in the world that would disregard the role of the teacher in the education process. Although these systems differ so much, they agree that good education and upbringing can be the work of a good teacher-tutor" ${ }^{6}$

The effectiveness of education for blind and visually impaired students is determined by various factors. These factors include the

${ }^{4}$ Z. Janiszewska-Nieścioruk, M. Zaorska, Prowłączające zmiany w systemie polskiej edukacji - nowe możliwości, ograniczenia i wyzwania (Pro-integrative Changes in the Polish Educational System - New Opportunities, Limitations and Challenges), „Interdyscyplinarne konteksty pedagogiki specjalnej” 2014, no. 4, pp. 9-28.

${ }^{5}$ M. Rutkowski, K. Bidziński, Nauczyciele szkoty ogólnodostępnej - realizatorzy idei edukacji wtaczającej - w poszukiwaniu źródet zawodowego wsparcia (Teachers of Public School - Implementers of the Idea of Inclusive Education - In Search of Sources of Professional Support), [in:] Jest czlowiek z niepetnosprawnościa. Pola refleksji (A Person with a Disability. Fields of Reflection), eds. B. Antoszewska, I. Myśliwczyk, Wydawnictwo Naukowe SILVA RERUM, Poznań-Olsztyn 2017, pp. 167-186.

${ }^{6}$ W. Okoń, Wprowadzenie do dydaktyki ogólnej (Introduction to General Education). Żak, Warszawa, 1996, p. 423, after: Kompetencje diagnostyczne $i$ terapeutyczne nauczyciela (The Diagnostic and Therapeutic Competence of the Teacher), eds. D. WosikKawala, T. Zubrzycka-Maciąg, Oficyna Wydawnicza „Impuls”, Kraków 2011, p. 7. 
preparation of an educational space, including adaptation of the environment and didactic aids, as well as resources of competences and attitudes of regular teachers, teachers of students with visual impairments -teacher assistants and other specialists working with a student who has a visual disability. It is obvious that the negative characteristics of any of these factors will limit the learning outcomes. ${ }^{7}$

In the teachers' opinion, considering their experience with all groups of children with special educational needs, it is the work with a visually impaired student that is the most difficult. ${ }^{8}$ Perhaps it is associated with cognitive dissonance, which Iwona Chrzanowska points out. "According to Festinger's theory, the lack of reliable assessment of the situation, as a result of not having knowledge about the specifics of the functioning of people with disabilities, creates a sense of frustration, uncertainty and anxiety. (...) the appearance in the community of a person functioning differently can be perceived as a disturbance of the developed, cognitive assessment of reality". ${ }^{\prime \prime}$

The question then arises, what competencies should be inherent in a teacher of students with visual impairments, who works as a teacher assistant? On the one hand, competences must be a re-

${ }^{7}$ M. Rutkowski, Kompetencje diagnostyczne, planistyczne, realizacyjne i ewaluacyjne w pracy z uczniami ze specjalnymi potrzebami edukacyjnymi - w ocenie wtasnej nauczycieli uczacych w placówkach specjalnych oraz integracyjnych (Diagnostic, Planning, Implementation and Evaluation Competences in Working with Students with Special Educational Needs - The Own Assessment of Teachers in Special and Integrative Institutions), "Pedagogika. badania, dyskusje, otwarcia". Dzieci i młodzież ze specjalnymi potrzebami edukacyjnymi. Implikacje dla teorii i praktyki (Children and Youth with Special Educational Needs. Implications for Theory and Practice), issue 3/2014, pp. 47-64.

${ }^{8}$ D.Al. Khamisy, Edukacja wtaczajaca edukacja dialogu. W poszukiwaniu modelu edukacji ucznia ze specjalnymi potrzebami edukacyjnymi (Inclusive Education as the Education of Dialogue. In Search of a Model of Education for Students with Special Educational Needs). Wydawnictwo Akademii Pedagogiki Specjalnej, Warsaw 2013.

${ }_{9}^{9}$ I. Chrzanowska, Nauczanie inkluzyjne w doświadczeniach polskich - podstawy prawne i społeczne uwarunkowania (Inclusive Teaching in the Polish Experience - Legal and Social Conditions). „Studia Edukacyjne” 2014, no. 30, p. 113. 
sponse to the contemporary needs of a student with a visual disability, his teachers, parents. On the other hand, universities educating future teacher of students with visual impairments are not able to equip their graduates with all the competences needed when working with blind and visually impaired students.

\section{The spectrum of professional competences of a special educator}

As Małgorzata Kupisiewicz points out, special pedagogy has long ceased to have the status of only special school pedagogy, at a time when its foundations were shaped by Maria Grzegorzewska. ${ }^{10}$ Therefore, the role and tasks of the special educator change. The teaching profession appears to be particularly difficult because it requires many qualifications (often very specialized ones), specific attitudes, both cultural, intellectual, as well as moral, social and psychological. At the same time, it requires highly developed teaching skills, supported by a wealth of individual information resources from various fields of science. ${ }^{11}$

An expression of interest in teaching competences is the presence in literature on pedeutology of many classifications that attempt to create the image of desired skills that are to ensure teacher's effectiveness. A holistic approach to competences in the teacher's work includes knowledge in the field of his profession and related fields, practical skills, including diagnosis, pragmatism and evalua-

${ }^{10}$ M. Kupisiewicz, Pedagog specjalny - człowiek o wyjątkowych predyspozycjach osobowościowych, profesjonalista posiadajacy rozległa, interdyscyplinarna wiedze $i$ umiejętności (Special Education Teacher - A Person with Exceptional Personality Traits, a Professional with Extensive, Interdisciplinary Knowledge and Skills), "Studia z teorii wychowania" 2016, vol. VII, no. 4(17), pp. 173-184.

${ }_{11} \mathrm{M}$. Konieczna-Kucharska, Miękkie i twarde kompetencje nauczycieli (Soft and Hard Competences of Teachers), "Zeszyty Naukowe Politechniki Częstochowskiej Zarządzanie" 2015, no. 19 pp. 229-241, <http://www.zim.pcz.pl/znwz> [access: 28.05.2019]. 
tion, as well as moral awareness, personal characteristics and predispositions. ${ }^{12}$

The term of competences is used in the context of behavioural (socalled soft) and functional (so-called hard) competences. The first group defines the way people should behave to do their job well. Therefore, this group of competences include, among others, personal skills, character and temperament traits, attitudes, social and communication skills. Thanks to them, it is primarily possible to manage yourself, your time and others, plan and anticipate, function in society, including the ability to work in a team, as well as motivate to act, both yourself and others, assertiveness, creativity and emotional intelligence. Hard competences relate to specific skills, qualifications and knowledge. This group of competences includes, among others, skills related to the adaptation of educational tasks, the pace of their implementation to the level of development, opportunities and learning style of students. ${ }^{13}$

The spectrum of competences of a special needs counsellor can be outlined by dividing them into seven main groups. The first group consists of substantive skills related to the implementation of the teaching and improvement process, including correction and compensation, as well as efficiency in the use of various therapeutic methods and techniques. The second group consists of didactic as well as psychological and pedagogical competences regarding didactic diagnosis, planning, organizing, controlling and evaluating the course and results of educational processes, with particular emphasis on the specific needs and functioning of individual students with special educational needs. An important group of competences are communication competences, which manifest themselves,

12 M. Zaorska, Rola i miejsce pedagoga specjalnego w kreowaniu działalności edukacyjno-terapeutycznej (The Role and Place of Special Needs Counselor in Creating Educational and Therapeutic Activity), "Acta Universitatis Nicolai Copernici Pedagogika" 2012, vol. XXVIII (405), pp. 13-23.

${ }^{13}$ M. Konieczna-Kucharska, Miękkie i twarde kompetencje nauczycieli (Soft and Hard Competences of Teachers), "Zeszyty Naukowe Politechniki Częstochowskiej Zarządzanie" 2015, no. 19 pp. 229-241, <http://www.zim.pcz.pl/znwz> [access: 28.05.2019]. 
among others in the scope of knowledge and communication skills using verbal as well as supportive and alternative methods of interpersonal communication. Cooperation competences are expressed in the form of pro-social behaviour, especially the skills to shape them in students, as well as skills in solving difficult and problem situations, also in the areas of integration activities.

Creative competences are extremely important in the context of seeking and creating methods, didactic and therapeutic techniques as well as developing materials and didactic aids, taking into account the individual needs and capabilities of students with special educational needs. It is impossible to function without technology in the modern world. Therefore, the broadly understood IT competences are those thanks to which a teacher or special needs counsellor can effectively use modern technologies, acquiring information, communicating with students, preparing and adapting teaching materials.

Personality as well as moral and ethical competences are characterized by humanitarianism. It is expressed by the recognition of the student's subjectivity, regardless of the type and degree of his or her disability. It is also responsibility, honesty, empathy, perseverance and consistency, as well as self-criticism and the capability of an indepth moral reflection. ${ }^{14}$ Ethical values, personal standards regarding behaviour in the work environment and performance of professional tasks, as well as individual predispositions fall within the area of soft competences resulting from deeply rooted personality structures. They are the potential and resources of a special educator to effectively work for the benefit of people with disabilities. ${ }^{15}$

${ }_{14}$ M. Kupisiewicz, Pedagog specjalny - człowiek o wyjątkowych predyspozycjach osobowościowych, profesjonalista posiadajacy rozległa, interdyscyplinarna wiedzę $i$ umiejętności (Special Education Teacher - A Person with Exceptional Personality Traits, a Professional with Extensive, Interdisciplinary Knowledge and Skills), "Studia z teorii wychowania” 2016, vol. VII, no. 4(17), „Studia z teorii wychowania” 2016, vol. VII, no. 4(17), pp. 173-184.

${ }^{15}$ M. Wolan-Nowakowska, Znaczenie kompetencji spotecznych w pracy pedagoga specjalnego (The Importance of Social Competence in the Work of a Special Needs Teacher), „Lubelski rocznik pedagogiczny” 2016, vol. XXXV, issue 3, pp. 153-163. 
The multitude of teaching specialties prevents a comprehensive description of competences. This description allows, however, to selectively relate to competences resulting from the specifics of working with a unique group of students, as well as in an assumptive way, referring to the concept of human experience in the area of significant, basic categories. ${ }^{16}$

\section{Teacher of students with visual impairments as a teacher assistant - competences and expectations}

According to the current approach to inclusive education, and therefore in accordance with the needs of a generally accessible school, a teacher assistant (and in this role, a teacher of students with visual impairments) should possess a wide range of competences, especially highly specialised ones, which cannot possibly be acquired in the course of academic studies by any student majoring in teaching children with visual impairments (as regards full-time, part-time and postgraduate studies alike). As we examine substantive competences alone, we should note that it is expected that a teacher of students with visual impairments is expected to be able to work with a diverse group of students. Such a group will include blind children, as well as students with poor sight (those with a stable level of visual functioning, but also those who happen to be losing their sight quite rapidly or gradually as a result of visual system conditions). The support of a teacher of student with visual impairments is also granted to children with little or no sight, at the same time suffering from multiple disabilities, be it diagnosed or

16 S. Byra, Z. Kazanowski, Postrzeganie kompetencji zawodowych nauczyciela w edukacji inkluzyjnej - próba pomiaru (The Perception of Teacher's Professional Competence in Inclusive Education - An Attempt at Measurement), [in:] W poszukiwaniu indywidualnych dróg wspierajacych wszechstronny rozwój osób z niepetnosprawnościa (In Search of Individual Approach to Support the Comprehensive Development of People with Disabilities), eds. B. Szczupał, A. Giryński, G. Szumski, Wydawnictwo Akademi Pedagogiki Specjalnej, Warsaw 2015, pp. 247-260. 
not. It follows from practical observations that additional disabilities of a student with little or no sight, such as e.g. intellectual disabilities (especially mild ones), or autism spectrum disorders, are diagnosed in the course of school education. A group of children with multiple disabilities also includes students whose visual impairment results from brain damage, who suffer from chronic diseases, e.g. diabetes, epilepsy, as well as children whose visual impairment results from or coexists with a cancer. This refers e.g. to students with tumours of deep brain structures, whose visual impairments, epilepsy or intellectual disability are secondary consequences of the cancer. ${ }^{17}$ Therefore, the spectrum of co-morbidities and conditions coexisting with visual impairments or blindness is rather broad. Additionally, it should be emphasised that the methodology of working with students with visual impairments is completely different from working with a blind student, which is why the scope of knowledge and skills of a prospective teacher must be really wide.

When analysing the needs of blind students and the school environment in detail, it is expected that the teacher of students with visual impairments will possess highly specialised competences related to teaching the Braille tactile writing system, which in turn includes the preparation for tactile reading and the development of tactile perception, as well as the knowledge of advanced Braille notation: mathematical, physical, chemical, musical, or Polish Braille abbreviations. The awareness of the significance of graphic education of blind students is the starting point for the teaching methodology of tactile graphics 18 , which is why the teacher's knowledge and competences in this respect are vital.

${ }_{17}$ M. Paplińska, M. Walkiewicz-Krutak, Visual impairment as a consequence of brain tumour: difficulties experienced by the child in spatial orientation, and in the cognitive, social and communication areas, "Człowiek-Niepełnosprawność-Społeczeństwo" 2018, no. 2(40), pp. 15-27.

${ }_{18}$ M. Paplińska, Edukacja graficzna uczniów z niepetnosprawnościa wzroku odzwierciedlona w IPETach - ważny czy pomijany obszar wsparcia (Graphic Education of Students with Visual Impairment reflected in IPETs - Important or Omitted Areas of Support), [in:] 
It's hard to imagine that a teacher assistant, who works with a blind student, doesn't understand the implications of blindness and cannot use compensation methods to support a child and help them understand certain notions, including spatial and surrogate notions, when teaching them to gain access to information with the use of special teaching aids. The ability to choose correct teaching aids, which are often prepared by the teachers themselves, and to adapt teaching materials to include Braille notation is one of the key competences in order to provide efficient support to a blind student.

It is also expected that a teacher of students with visual impairments as a teacher assistant will also educate the school environment and the community outside. This includes any activities aimed at popularising the awareness of people with visual impairments. ${ }^{19}$ Therefore, the most important competences and skills are those that will help the teacher boost social integration of visually impaired students with their healthy peers at school, by spreading knowledge about people with poor or no sight, their needs and abilities, as well as debunking myths and eliminating prejudice.

It is usually the case that except for schools and educational centres for children and youth with visual impairments, blind students do not have any classes in spatial orientation, moving around or everyday activities. Therefore, a teacher assistant is also expected to possess a full set of competences needed to teach the students how to move around and protect themselves. This includes moving around with a sighted guide and with a long white cane. Such

Jest człowiek z niepetnosprawnością. Pola refleksji (A Person with a Disability. Fields of Reflection), eds. B. Antoszewska, I. Myśliwczyk, Wydawnictwo Naukowe SILVA RERUM, Poznań-Olsztyn 2017, pp. 205-229.

${ }^{19}$ M. Paplińska, J. Witczak-Nowotna, Tyfloedukacja jako element budowania integracji społecznej uczniów niewidomych $i$ stabowidzacych w edukacji wtaczajacej (Teaching Students with Visual Impairments as Part of Building Social Integration of Blind and Visually Impaired Students in Inclusive Education), [in:] Tyflopedagogika wobec wspótczesnej przestrzeni edukacyjno-rehabilitacyjnej (Teaching Students with Visual Impairments Against the Background of Contemporary Educational and Rehabilitation Space), eds. K. Czerwińska, M. Paplińska, M. Walkiewicz-Krutak, Wydawnictwo Akademii Pedagogiki Specjalnej, Warsaw 2015, pp. 114-134. 
needs also include basic rehabilitation skills, which the teacher of students with visual impairments should have.

While we remember that a vast majority of poorly sighted children attend inclusive education, which means they attend mainstream schools, there is a great demand for professional assistants teachers of students with visual impairments - in such schools. When working with students with visual impairments, it is important to remember about the crucial set of competences related to the improvement of visual functioning. This area includes a choice of proper aids (optical and non-optical), as well as the ability to adapt teaching aids to individual needs, related to functional implications of specific visual conditions. Expectations related to teachers of students with visual impairments also include teaching spatial orientation, including the interpretation of available visual information and improving the sight. A teacher of students with visual impairments who is also qualified as a visual rehabilitation specialist will support students in developing advanced visual skills, which make it easier for him/her to access information, communicate and be independent.

People with visual impairments may effectively use modern technologies, especially educational assistive technologies, to compensate for the lack of or limited access to information, mainly visual, which is necessary to gain knowledge, communicate and move around.

It follows from the analysis of teachers' competences as regards the use of assistive technologies when working with people with visual impairments that teachers lack these competences. Although international studies with the participation of 38 subjects from 273 countries show that educational assistive technologies are usually included in the curriculum of candidates studying to become teachers of students with visual impairments, the teachers themselves claim their skills are poor in this respect. Among the most frequent reasons for this they quote: diverse groups and diverse needs of children with visual impairments, which requires particular effort and there may be not enough time to select new technologies and 
support students in this process. Another argument is the lack of opportunities for developing the skills acquired during the studies, as technological solutions are subject to rapid changes. ${ }^{20}$

The most difficult tasks faced by special education teachers are those related to a reliable, complex functional diagnosis of a student. Diagnostic competences of teachers working with blind students and those with visual impairments require a creative integration of knowledge and skills from a wide variety of areas. Diagnosing a blind or visually impaired student is a challenge, considering the diversity of the group of visually impaired children and a multitude of areas that require specialised, extensive knowledge. Plus, there are not enough reliable and available diagnostic tools. The awareness of functional conditions of the visual system as well as proper diagnosis of visual functioning of a visually impaired child is the foundation for the proper diagnosis of their needs as well as for the choice of appropriate optical, non-optical and electronic aids. In the case of a child who is blind or is losing their sight, the diagnosis of their functioning at school and at home includes: understanding notions, readiness to learn tactile reading, degree of familiarity with the Braille reading and writing system, including the use of Braille tools and devices, the ability to read and prepare tactile graphics, as well as the skills related to spatial orientation and moving around, and self-care activities corresponding to the child's needs, abilities and age. ${ }^{21}$ As Joanna Głodkowska em-

${ }^{20}$ E. Śmiechowska-Petrovskij, Kompetencje nauczycieli uczniów niewidomych i stabowidzacych w zakresie wspomagajacych technologii informacyjno-komunikacyjnych (Competences of Teachers of Blind and Partially Sighted Students with Respect to Assistive Information and Communication Technologies), „Niepełnosprawność. Dyskursy pedagogiki specjalnej". Niepełnosprawności złożone i sprzężone - konteksty normalizacji oraz psychospołecznej aktywizacji (Complex and Interlinked Disability - Contexts of Standardisation and Psychosocial Activation), 2016, no. 21, Gdańsk, pp. 106-120.

${ }^{21}$ M. Paplińska, J. Witczak-Nowotna, Kompleksowa diagnoza dziecka niewidomego, jego sytuacji w domu i szkole - studium przypadku (Comprehensive Diagnosis of a Blind Child, Situation at Home and at School. A Case Study), [in:] Diagnoza i metody wspomagania rozwoju (Diagnosis and Methods of Development Assistance), eds. B. Antoszewska, M. Wójcik, Uniwersytet Warmińsko-Mazurski, Olsztyn 2015, pp. 71-89. 
phasises, knowledge about a student is the basis for diagnosing and designing any further actions. It is important that the teacher is able to conduct a reliable, complex diagnosis and recognise various areas of functioning (comprehensive diagnosis). The teacher should be able to recognise not only disorders and difficulties, but also strengths and developmental advantages of a student (positive diagnosis). Teachers should be able to use appropriate measurement tools to define developmental profiles (profiling diagnosis). They should also focus on following the child's development and capturing any changes (dynamic diagnosis), and should be able to interpret the outcomes of a diagnosis in a conscientious and appropriate manner, so as to define the student's needs and abilities (prognostic diagnosis). ${ }^{22}$

Considering the fact that diagnostic competences of a special education teacher are of key importance and the diagnosis itself requires special skills, it should be emphasised that the process of becoming a diagnostician and a teacher is constructive and cumulative. It is fully consistent with the idea of lifelong learning. It is impossible to equip prospective teachers with a complete set of skills needed to conduct a reliable, multifaceted diagnosis. This requires experience and certain internal personality traits.

\section{Educating teachers of students with visual impairments - current status and potential changes}

As Stefan Kwiatkowski emphasizes, "meeting the requirements set for modern school counsellors turns out to be a task that is incomparably more difficult than before. Only properly trained specialists can count on achieving professional success in schoolwork, who have successfully gone through the entire educational process, taking into account all the necessary elements" ${ }^{23}$

22 J. Głodkowska, Dydaktyka specjalna. Od wzorca do interpretacji (Special Education. From Standard to Interpretation), PWN, Warsaw 2017, pp. 40-41.

23 S.T. Kwiatkowski, Znaczenie ksztatcenia społeczno-emocjonalnego w rozwijaniu kluczowych kompetencji wspótczesnych nauczycieli (The Significance of Socio-emotional 
Careful preparation of methodical and practical specialization classes serves the development of professional competences of future teachers of students with visual impairments at the Academy of Special Education in Warsaw. By experiencing in a simulated situation of blindness or impaired vision (headbands and simulators of impaired vision are used), students have the direct opportunity to perform various tasks and activities while facing cognitive, emotional and social difficulties. It is learning through experiencing and acting, once as a student, once as a teacher. This kind of experience stimulates reflection and allows us to better understand the difficulties faced by blind and visually impaired people. Through the personal involvement of future teachers of students with visual impairments, it also gives students the chance to develop their own didactic strategies. In addition, workshop-and-lecture classes allow students to be better prepared for apprenticeships and later for work.

The analysis of the professional activity of graduates of the teacher of students with visual impairments specialization showed that the majority of people after completing their studies improved their professional competences through courses and trainings as well as postgraduate studies, which proves that graduates of the studies to become a teacher of students with visual impairments play a great role in their professional development. This is desirable and corresponds to the model of an individualized career path. ${ }^{24}$

Zdzisława Janiszewska-Nieścioruk and Marzenna Zaorska point out that acquiring the competences of future special education

Education in the Development of Key Competences of Contemporary Teachers), [in:] Kompetencje interpersonalne w pracy wspótczesnego nauczyciela (Interpersonal Competences in a Modern Teacher Work), eds. S.T. Kwiatkowski, D. Walczak, Wydawnictwo akademii Pedagogiki Specjalnej, Warsaw 2017, p. 133.

${ }^{24}$ K. Czerwińska, K. Miler-Zdanowska, Tyflopedagog we wspótczesnej przestrzeni edukacyjnej (Teacher of Students with Visual Impairments in Contemporary Educational Space), [in:] Tyflopedagogika wobec wspótczesnej przestrzeni edukacyjno-rehabilitacyjnej (Teaching Students with Visual Impairments Against the Background of Contemporary Educational and Rehabilitation Space), eds. K. Czerwińska, M. Paplińska, M. Walkiewicz-Krutak, Wydawnictwo Akademii Pedagogiki Specjalnej, Warsaw 2015, pp. 12-43. 
counsellors in the course of two-cycle studies is ostensible in its character. The authors emphasize that "allowing full competence to work with students with disabilities and / or special needs to graduates after completing their first cycle of studies is highly inadequate and redundant, especially since they could have obtained them after completing two or even three specializations within just three years of study $(\ldots)^{\prime \prime} \cdot 25$

Therefore, a return from the 2019/2020 academic year to a fiveyear master's course in special education will allow graduates of the programme for teachers of students with visual impairments (as part of the uniform study program) to obtain additional competences, including to work as an eye rehabilitator, teacher of spatial orientation or Braille teacher. Unfortunately, despite the fact that many teachers of students with visual impairments have full qualifications and competences, and what is more, they successfully work as sight rehabilitators with visually impaired people, or as teacherinstructors of spatial orientation and independent movement of blind and visually impaired people, none of these professions is included in the list of professions. Registration of new professions and giving them a formal character seems necessary, not least because the demand for the services of these specialists is relatively high.

When analyzing the development of Polish field of expertise among teachers of students with visual impairments, Marzenna Zaorska determined the categories of its successes and (un)successes. In addition to achievements, such as the emergence of courses for teachers of students with visual impairments established as a subdiscipline of academic and practical special pedagogy, or the implementation, improvement of the quality and effectiveness of highly humanistic activities for the subject and practice, the author draws attention to "making the domain of teachers of students with

25 Z. Janiszewska-Nieścioruk, M. Zaorska, Prowłączające zmiany w systemie polskiej edukacji - nowe możliwości, ograniczenia i wyzwania (Pro-integrative Changes in the Polish Educational System - New Opportunities, Limitations and Challenges), "Interdyscyplinarne konteksty pedagogiki specjalnej" 2014, no. 4, p. 21. 
visual impairments a specialization in pedagogy, which means broader and more purposeful education of specialists to work with people with visual disabilities, development of staff operating in academic and practical pedagogy for teachers of students with visual impairments". ${ }^{26}$ Among the so-called (non)successes were the lack of preselection of candidates for the profession of a teacher of students with visual impairments and the lack or shortage of obligatory subjects in this field in pedagogical study programs, which entails negative consequences regarding knowledge, competences and skills related to work and educational and rehabilitation support of students with sight disabilities.

Competences are not a permanent feature. Their acquisition and development depend on the teacher, their commitment, skills, motivation and pursuit of self-development. ${ }^{27}$ Therefore, it is impossible to determine when the teacher will be able to state that he or she has already mastered the full range of necessary knowledge, skills and competences. ${ }^{28}$ It is worth emphasizing, however, that the apparent sense of achieving full competence may also become a trap

${ }^{26}$ M. Zaorska, Tyflopedagogika wobec wyzwań rozwoju wspótczesnej nauki i cywilizacji (Teaching Students with Visual Impairments in the Face of the Developmental Challenges of Modern Science and Civilization), [in:] Tyflopedagogika wobec różnorodności wspótczesnych wyzwań edukacyjno-rehabilitacyjnej (Teaching Students with Visual Impairments in the Face of the Diverse Challenges of Modern Education and Rehabilitation), eds. K. Czerwińska, K. Miler-Zdanowska, Wydawnictwo Akademii Pedagogiki Specjalnej, Warsaw 2017, p. 19.

27 J. Gasik, Pedagog specjalny w kształceniu uczniów ze specjalnymi potrzebami edukacyjnymi (Special Education Councellor in the Education of Students with Special Educational Needs), [in:] Dydaktyka specjalna w przygotowaniu do ksztatcenia uczniów ze specjalnymi potrzebami edukacyjnymi (Special Education in Preparation for the Education of Students with Special Educational Needs), ed. J. Głodkowska, Wydawnictwo Akademii Pedagogiki Specjalnej, Warsaw 2010, pp. 250-273.

28 S.T. Kwiatkowski, Znaczenie kształcenia społeczno-emocjonalnego w rozwijaniu kluczowych kompetencji wspótczesnych nauczycieli (The Significance of Socio-emotional Education in the Development of Key Competences of Contemporary Teachers), [in:] Kompetencje interpersonalne w pracy wspótczesnego nauczyciela (Interpersonal Competences in a Modern Teacher Work), eds. S.T. Kwiatkowski, D. Walczak, Wydawnictwo Akademii Pedagogiki Specjalnej, Warsaw 2017, pp. 125-158. 
in which a special education teacher, especially an experienced specialist in narrow, highly specialized areas, is convinced of their omnipotence in the sphere of diagnosis, support for a child with disabilities. This, in turn, entails the phenomenon of positive and negative authority, described by researchers ${ }^{29}$, with all its consequences, among others, for the teacher-student relationship. Especially when working with students with vision disabilities, in whom the diseases of the visual system are often progressive, and therefore the changes are dynamic and require adaptation to the new situation and different conditions, one cannot define a full knowledge of the pedagogy in the specialization of a teacher of students with visual impairments, concerning the future of the child. Resignation from controlling the student's development in support of their development requires the teacher to limit the attitude of the dictate in favour of dialogue in an attitude of self-reflection and openness. ${ }^{30} \mathrm{It}$ is important, however, that the teacher of students with visual im-

${ }^{29}$ Cf. B. Skałbania, Nauczyciel jako aktor szkolnej codzienności - aspekty dramaturgii i wtadzy (Teacher as an Actor of Everyday School Life. Aspects of Drama and Power), [in:] Nauczyciel we wspótczesnej edukacji. Diagnoza - Rozwój - Zmiana (Teacher in Modern Education. Diagnosis - Development - Change), eds. M Kamińska, Z.P. Kruszewski, A. Gretkowski, B. Skałbania, Szkoła Wyższa im. Pawła Włodkowica in Płock, PłockWarsaw 2016, pp. 139-347; S. Sadowska, O wtadzy nauczycielskiej - jasne i ciemne strony wtadzy w kontekście integracji (On Teacher's Power - The Bright and Dark Sides of Power in the Context of Integration), [in:] Od tradycjonalizmu do ponowoczesności (From Traditionalism to Postmodernity), eds. E. Górniewicz, A. Krause, Wydawnictwo UWM, Olsztyn 2002, pp. 289-298.

T. Żółkowska, Normalizacja - niedokończona teoria praktyki (Standardisation The Unfinished Theory of Practice), "Niepełnosprawność" 2011, no. 5, pp. 85-93, <http:/ / bazhum.muzhp.pl/media/ / files/Niepelnosprawnosc/Niepelnosprawnosc -r2011-t-n5/Niepelnosprawnosc-r2011-t-n5-s85-93/Niepelnosprawnosc-r2011-t-n5s85-93.pdf>, [accesses: 28.05.2019].

${ }^{30}$ M. Rutkowski, K. Bidziński, Nauczyciele szkoły ogólnodostępnej - realizatorzy idei edukacji włączającej - w poszukiwaniu źródeł zawodowego wsparcia (Teachers of Public School - Implementers of the Idea of Inclusive Education - In Search of Sources of Professional Support), [in:] Jest człowiek z niepetnosprawnością. Pola refleksji (A Person with a Disability. Fields of Reflection), eds. B. Antoszewska, I. Myśliwczyk, Wydawnictwo Naukowe SILVA RERUM, Poznań-Olsztyn 2017, pp. 167-186. 
pairments - a teacher assistant - is substantively and methodically prepared to respond to the current needs of a blind and visually impaired child. The teacher should be able to draw conclusions from practice and diverse experiences.

Building the awareness of pedagogical students that the initial stage of education is just the starting point for a continued education and professional development can counteract the future negative phenomena of power/authority and omnipotence of specialist teachers involved in the educational and rehabilitation process of children with special educational needs. Looking closely at one of the classification of competences of a special educator proposed by Zofia Szynkowska ${ }^{31}$, one can reflect that the development of the socalled basic competences, i.e. the first and basic ones, which are broadly understood social, intellectual and moral skills, are beyond the scope of pedagogical universities, although opportunities for their development are and should be arranged during classes.

\section{Summary}

Social expectations towards teachers are often too steep and sometimes impossible to implement. Teachers are treated as a group for which specific personality traits are required, as well as meeting various professional tasks, and to have competences "immediately". 32 The profession of a special education counsellor belongs to the group of subject professions focused on working with another person, therefore, apart from theoretical and substantive preparation of

31 Z. Szynkowska, Program nauczania a kompetencje nauczyciela (The Curriculum vs. Teacher Competence), [in:] Kompetencje zawodowe nauczycieli a problemy reformy edukacyjnej (Professional Competences of Teachers and Problems with Educational Reform), ed. E. Sałata, Wydawnictwo Politechniki Radomskiej, Radom 2001.

$32 \mathrm{~J}$. Giedyk-Miko, Oczekiwania wobec nauczyciela oraz jego roli w środowisku wiejskim - w świetle wypowiedzi studentów pedagogiki urodzonych i wychowanych na wsi (Expectations Towards the Teacher and His or Her Role in the Rural Environment - In the Light of the Statements by Students of Pedagogy Born and Raised in Rural Areas), „Rozprawy Społeczne” 2014, vol. VIII, no. 3, pp. 48-56. 
interdisciplinary character, it requires numerous practical competences, as well as special internal predispositions - personal ones, including characterological and empathic, and deepened moral and ethical awareness.

Analyzing just the substantive competences of a teacher of students with visual impairments needed for effective and successful work with blind and visually impaired students, it can be argued that this is one of the special needs tutors equipped with the most specialist skills.

As Stefan T. Kwiatkowski emphasizes, "students of pedagogical sciences should be made clearly aware during their studies that the education obtained in their Alma Mater, even if the university occupies first place in prestigious rankings, will never be sufficient and is only the foundation necessary for continuous development of their potential and including new forms of problem solving in the arsenal of their behaviour resulting from the experience acquired in the course of professional work". ${ }^{33}$ In addition to this awareness among graduates of pedagogical faculties, it is also important to monitor the effects of changes in the model of preparing teachers to work with students with special educational needs. The teachers' needs in the area of improving their professional competences should be translated, among others to training offer, post-graduate studies, etc. ${ }^{34}$

33 S.T. Kwiatkowski, Znaczenie ksztatcenia społeczno-emocjonalnego w rozwijaniu kluczowych kompetencji wspótczesnych nauczycieli (The Significance of Socio-emotional Education in the Development of Key Competences of Contemporary Teachers), [in:] Kompetencje interpersonalne w pracy współczesnego nauczyciela (Interpersonal Competences in a Modern Teacher Work), eds. S.T. Kwiatkowski, D. Walczak, Wydawnictwo akademii Pedagogiki Specjalnej, Warsaw 2017, p. 130.

34 S. Byra, Z. Kazanowski, Postrzeganie kompetencji zawodowych nauczyciela w edukacji inkluzyjnej - próba pomiaru (The Perception of Teacher's Professional Competence in Inclusive Education - An Attempt at Measurement), [in:] W poszukiwaniu indywidualnych dróg wspierających wszechstronny rozwój osób z niepetnosprawnościa (In Search of Individual Approach to Support the Comprehensive Development of People with Disabilities), eds. B. Szczupał, A. Giryński, G. Szumski, Wydawnictwo APS, Warszawa 2015, pp. 247-260. 
Education for inclusion at school is an important dimension of teacher training today. For inclusive education not to be merely apparent, it is necessary to shape favourable social attitudes, prepare competent staff equipped with knowledge about the possibilities, needs and conditions that must be met in order for a child to participate effectively in education. ${ }^{35}$

\section{Bibliography}

[1] Al.-Khamisy D., Edukacja wtaczająca edukacją dialogu. W poszukiwaniu modelu edukacji ucznia ze specjalnymi potrzebami edukacyjnymi (Inclusive Education as the Education of Dialogue. In Search of a Model of Education for Students with Special Educational Needs), Wydawnictwo Akademii Pedagogiki Specjalnej, Warsaw 2013.

[2] Byra S., Kazanowski Z., Postrzeganie kompetencji zawodowych nauczyciela w edukacji inkluzyjnej - próba pomiaru (The Perception of Teacher's Professional Competence in Inclusive Education - An Attempt at Measurement), [in:] W poszukiwaniu indywidualnych dróg wspierających wszechstronny rozwój osób z niepetnosprawnościq (In Search of Individual Approach to Support the Comprehensive Development of People with Disabilities), eds. B. Szczupał, A. Giryński, G. Szumski, Wydawnictwo APS, Warsaw 2015, pp. 247-260.

[3] Chrzanowska I., Nauczanie inkluzyjne w doświadczeniach polskich - podstawy prawne $i$ spoteczne uwarunkowania (Inclusive Teaching in the Polish Experience Legal and Social Conditions), „Studia Edukacyjne” 2014, no. 30, pp. 109-117.

[4] Czerwińska K., Miler-Zdanowska K., Tyflopedagog we wspótczesnej przestrzeni edukacyjnej (Teacher of Students with Visual Impairments in Contemporary Educational Space), [in:] Tyflopedagogika wobec wspótczesnej przestrzeni edukacyjnorehabilitacyjnej (Teaching Students with Visual Impairments Against the Background of Contemporary Educational and Rehabilitation Space), eds. K. Czerwińska, M. Paplińska, M. Walkiewicz-Krutak, Wydawnictwo Akademii Pedagogiki Specjalnej, Warsaw 2015, pp. 12-43.

[5] Dycht M., Edukacja i wspieranie uczniów ze specjalnymi potrzebami edukacyjnymi i rozwojowymi w placówkach oświatowych w Polsce (Education and Support for Students with Special Educational and Developmental Needs in Educational Institutions

${ }^{35}$ I. Chrzanowska, Nauczanie inkluzyjne w doświadczeniach polskich - podstawy prawne $i$ spoteczne uwarunkowania (Inclusive Teaching in the Polish Experience - Legal and Social Conditions), „Studia Edukacyjne” 2014, no. 30, pp. 109-117. 
in Poland), [in:] Dzieci z trudnościami rozwojowymi w młodszym wieku. Indywidualne programy edukacyjno-terapeutyczne w procesie wspierania dzieci (Children with Developmental Handicaps at a Younger Age. Individual Educational and Therapeutic Programs in the Process of Supporting Children), ed. E. Śmiechowska-Petrovskij, Wydawnictwo Naukowe UKSW, Warsaw, 2017, pp. 11-36.

[6] Gasik J., Pedagog specjalny w ksztatceniu uczniów ze specjalnymi potrzebami edukacyjnymi (Special Education Councellor in the Education of Students with Special Educational Needs), [in:] Dydaktyka specjalna w przygotowaniu do ksztatcenia uczniów ze specjalnymi potrzebami edukacyjnymi (Special Education in Preparation for the Education of Students with Special Educational Needs), eds. J. Głodkowska, Wydawnictwo Akademii Pedagogiki Specjalnej, Warsaw 2010, pp. 250-273.

[7] Giedyk-Miko J., Oczekiwania wobec nauczyciela oraz jego roli w środowisku wiejskim - w świetle wypowiedzi studentów pedagogiki urodzonych $i$ wychowanych na wsi Expectations Towards the Teacher and His or Her Role in the Rural Environment - In the Light of the Statements by Students of Pedagogy Born and Raised in Rural Areas), "Rozprawy Społeczne" 2014, vol. VIII, no. 3, pp. 48-56.

[8] Głodkowska J., Dydaktyka specjalna. Od wzorca do interpretacji Special Education. From Standard to Interpretation, PWN, Warsaw 2017, pp. 40-41.

[9] Janiszewska-Nieścioruk Z., Zaorska M., Prowtaczające zmiany w systemie polskiej edukacji - nowe możliwości, ograniczenia i wyzwania (Pro-integrative Changes in the Polish Educational System - New Opportunities, Limitations and Challenges). "Interdyscyplinarne konteksty pedagogiki specjalnej" 2014, no. 4, pp. 9-28.

[10] Konieczna-Kucharska M., Miękkie i twarde kompetencje nauczycieli (Soft and Hard Competences of Teachers), "Zeszyty Naukowe Politechniki Częstochowskiej. Zarządzanie" 2015, no. 19, pp. 229-241, <http://www.zim.pcz.pl/znwz> [access: 28.05.2019].

[11] Kupisiewicz M., Pedagog specjalny - cztowiek o wyjatkowych predyspozycjach osobowościowych, profesjonalista posiadający rozległa, interdyscyplinarna wiedzę $i$ umiejętności (Special Education Teacher - A Person with Exceptional Personality Traits, a Professional with Extensive, Interdisciplinary Knowledge and Skills), "Studia z teorii wychowania" 2016, vol. VII, no. 4(17), pp. 173-184.

[12] Kwiatkowski S., Znaczenie ksztatcenia społeczno-emocjonalnego w rozwijaniu kluczowych kompetencji wspótczesnych nauczycieli (The Significance of Socio-emotional Education in the Development of Key Competences of Contemporary Teachers), [in:] Kompetencje interpersonalne w pracy wspótczesnego nauczyciela (Interpersonal Competences in a Modern Teacher Work), eds. S.T. Kwiatkowski, D. Walczak, Wydawnictwo Akademii Pedagogiki Specjalnej, Warsaw 2017, pp. 125-158.

[13] Okoń W., Wprowadzenie do dydaktyki ogólnej (Introduction to General Education). Żak, Warsaw 1996.

[14] Paplińska M., Edukacja graficzna uczniów z niepetnosprawnościa wzroku odzwierciedlona w IPETach - ważny czy pomijany obszar wsparcia (Graphic Education of 
Students with Visual Impairment reflected in IPETs - Important or Omitted Areas of Support), [in:] Jest człowiek z niepetnosprawnością. Pola refleksji (A Person with a Disability. Fields of Reflection), eds. B. Antoszewska, I. Myśliwczyk, Wydawnictwo Naukowe SILVA RERUM, Poznań-Olsztyn 2017, pp. 205-229.

[15] Paplińska M., Walkiewicz-Krutak M., Visual impairment as a consequence of brain tumour: difficulties experienced by the child in spatial orientation, and in the cognitive, social and communication areas, "Człowiek-Niepełnosprawność-Społeczeństwo" 2018, no. 2(40), pp. 15-27.

[16] Paplińska M., Witczak-Nowotna J., Kompleksowa diagnoza dziecka niewidomego, jego sytuacji w domu i szkole - studium przypadku (Comprehensive Diagnosis of a Blind Child, Situation at Home and at School. A Case Study), [in:] Diagnoza i metody wspomagania rozwoju (Diagnosis and Methods of Development Assistance), eds. B. Antoszewska, M. Wójcik, Uniwersytet Warmińsko-Mazurski, Olsztyn 2015, pp. 71-89.

[17] Paplińska M., Witczak-Nowotna J., Tyfloedukacja jako element budowania integracji społecznej uczniów niewidomych $i$ słabowidzacych w edukacji włączającej (Teaching Students with Visual Impairments as Part of Building Social Integration of Blind and Visually Impaired Students in Inclusive Education), [in:] Tyflopedagogika wobec wspótczesnej przestrzeni edukacyjno-rehabilitacyjnej (Teaching Students with Visual Impairments Against the Background of Contemporary Educational and Rehabilitation Space), eds. K. Czerwińska, M. Paplińska, M. Walkiewicz-Krutak, Wydawnictwo Akademii Pedagogiki Specjalnej, Warsaw 2015, pp. 114-134.

[18] Rutkowski M., Kompetencje diagnostyczne, planistyczne, realizacyjne i ewaluacyjne $w$ pracy $z$ uczniami ze specjalnymi potrzebami edukacyjnymi - w ocenie wtasnej nauczycieli uczących w placówkach specjalnych oraz integracyjnych (Diagnostic, Planning, Implementation and Evaluation Competences in Working with Students with Special Educational Needs - The Own Assessment of Teachers in Special and Integrative Institutions), „Pedagogika. Badania, dyskusje, otwarcia”. Dzieci i młodzież ze specjalnymi potrzebami edukacyjnymi. Implikacje dla teorii i praktyki (Children and Youth with Special Educational Needs. Implications for Theory and Practice), issue 3/2014, pp. 47-64.

[19] Rutkowski M., Bidziński K., Nauczyciele szkoły ogólnodostępnej - realizatorzy idei edukacji właczającej - w poszukiwaniu źródet zawodowego wsparcia (Teachers of Public School - Implementers of the Idea of Inclusive Education - In Search of Sources of Professional Support), [in:] Jest człowiek z niepetnosprawnością. Pola refleksji (A Person with a Disability. Fields of Reflection), eds. B. Antoszewska, I. Myśliwczyk, Wydawnictwo Naukowe SILVA RERUM, Poznań-Olsztyn 2017, pp. 167-186.

[20] Sadowska S., O władzy nauczycielskiej - jasne i ciemne strony władzy w kontekście integracji (On Teacher's Power - The Bright and Dark Sides of Power in the Context of Integration), [in:] Od tradycjonalizmu do ponowoczesności (From Traditionalism to Postmodernity), eds. E. Górniewicz, A. Krause, Wydawnictwo UWM, Olsztyn 2002, pp. 289-298. 
[21] Skałbania B., Nauczyciel jako aktor szkolnej codzienności - aspekty dramaturgii i wtadzy (Teacher as an Actor of Everyday School Life. Aspects of Drama and Power), [in:] Nauczyciel we wspótczesnej edukacji. Diagnoza-Rozwój-Zmiana (Teacher in Modern Education. Diagnosis - Development - Change), eds. M Kamińska, Z.P. Kruszewski, A. Gretkowski, B. Skałbania, Szkoła Wyższa im. Pawła Włodkowica in Płock, Płock-Warsaw 2016, pp. 139-347.

[22] Szynkowska Z., Program nauczania a kompetencje nauczyciela (The Curriculum vs. Teacher Competence), [in:] Kompetencje zawodowe nauczycieli a problemy reformy edukacyjnej (Professional Competences of Teachers and Problems with Educational Reform), ed. E. Sałata, Wydawnictwo Politechniki Radomskiej, Radom 2001.

[23] Śmiechowska-Petrovskij E., Kompetencje nauczycieli uczniów niewidomych i słabowidzacych $w$ zakresie wspomagajacych technologii informacyjno-komunikacyjnych (Competences of Teachers of Blind and Partially Sighted Students with Respect to Assistive Information and Communication Technologies), "Niepełnosprawność. Dyskursy pedagogiki specjalnej". Niepełnosprawności złożone i sprzężone - konteksty normalizacji oraz psychospołecznej aktywizacji (Complex and Interlinked Disability - Contexts of Standardisation and Psychosocial Activation), 2016, no. 21, pp. 106-120.

[24] Wolan-Nowakowska M., Znaczenie kompetencji społecznych w pracy pedagoga specjalnego (The Importance of Social Competence in the Work of a Special Needs Teacher), „Lubelski rocznik pedagogiczny” 2016, vol. XXXV, issue 3, pp. 153-163.

[25] Kompetencje diagnostyczne i terapeutyczne nauczyciela (The Diagnostic and Therapeutic Competence of the Teacher), eds. D. Wosik-Kawala, T. Zubrzycka-Maciagg, Oficyna Wydawnicza „Impuls”, Kraków 2011.

[26] Zaorska M., Rola i miejsce pedagoga specjalnego w kreowaniu działalności edukacyjno-terapeutycznej (The Role and Place of Special Needs Counselor in Creating Educational and Therapeutic Activity). "Acta Universitatis Nicolai Copernici Pedagogika" 2012, vol. XXVIII (405), pp. 13-23.

[27] Zaorska M., Tyflopedagogika wobec wyzwań rozwoju wspótczesnej nauki i cywilizacji (Teaching Students with Visual Impairments in the Face of the Developmental Challenges of Modern Science and Civilization), [in:] Tyflopedagogika wobec różnorodności wspótczesnych wyzwań edukacyjno-rehabilitacyjnych (Teaching Students with Visual Impairments in the Face of the Diverse Challenges of Modern Education and Rehabilitation), eds. K. Czerwińska, K. Miler-Zdanowska, Wydawnictwo Akademii Pedagogiki Specjalnej, Warsaw 2017, pp. 12-23.

[28] Żółkowska T., Normalizacja - niedokończona teoria praktyki (Standardisation - The Unfinished Theory of Practice), "Niepełnosprawność” 2011, no. 5, pp. 85-93, <http:// bazhum.muzhp.pl/media//files/Niepelnosprawnosc/Niepelnospraw nosc-r2011-t-n5/Niepelnosprawnosc-r2011-t-n5-s85-93/Niepelnosprawnosc-r20 11-t-n5-s85-93.pdf> [28.05.2019]. 